\title{
Corporate Governance and Its Political Economy
}

\section{Citation}

Mark J. Roe \& Massimiliano Vatiero, Corporate Governance and Its Political Economy (Harvard John M. Olin Discussion Paper Series Paper No. 827, May 2015).

\section{Published Version}

http://www.law.harvard.edu/programs/olin_center/papers/pdf/Roe_827.pdf

\section{Permanent link}

http://nrs.harvard.edu/urn-3:HUL.InstRepos:17742181

\section{Terms of Use}

This article was downloaded from Harvard University's DASH repository, and is made available under the terms and conditions applicable to Other Posted Material, as set forth at http:// nrs.harvard.edu/urn-3:HUL.InstRepos:dash.current.terms-of-use\#LAA

\section{Share Your Story}

The Harvard community has made this article openly available.

Please share how this access benefits you. Submit a story.

\section{Accessibility}




\title{
HARVARD
}

JOHN M. OLIN CENTER FOR LAW, ECONOMICS, AND BUSINESS

\author{
CORPORATE GOVERNANCE AND ITS POLITICAL ECONOMY \\ Mark J. Roe \\ Massimiliano Vatiero \\ Forthcoming in Oxford Handbook of Corporate Governance
}

Discussion Paper No. 827

$05 / 2015$

Harvard Law School

Cambridge, MA 02138

This paper can be downloaded without charge from:

The Harvard John M. Olin Discussion Paper Series:

http://www.law.harvard.edu/programs/olin_center/

The Social Science Research Network Electronic Paper Collection: http://ssrn.com/abstract=2588760

This paper is also a discussion paper of the John M. Olin Center's Program on Corporate Governance. 


\section{Corporate Governance and Its Political Economy}

Mark J. Roe and Massimiliano Vatiero

April 2, 2015 
Draft: April 2, 2015

\title{
CORPORATE GOVERNANCE AND ITS POLITICAL ECONOMY
}

\author{
Mark J. Roe and Massimiliano Vatiero
}

\begin{abstract}
To fully understand governance and authority in the large corporation, one must attend to politics. Because basic dimensions of corporate organization can affect the interests of voters, because powerful concentrated interest groups seek particular outcomes that deeply affect large corporations, because those deploying corporate and financial resources from within the corporation to buttress their own interests can affect policy outcomes, and because the structure of some democratic governments fits better with some corporate ownership structures than with others, politics can and does determine core structures of the large corporation. In this review piece for the Oxford Handbook on Corporate Governance, we analyze the generalities and then look at core aspects of corporate governance that have been, and continue to be, politically influenced and sometimes politically driven: first, the historically fragmented ownership of capital in the United States; second, the postwar power of labor in Europe and its corporate impact; and, third, the ongoing power of the American executive and the American board as due in part to their influence on political and legal outcomes.
\end{abstract}

JEL: G30, J50, K22, 016, P16.

Keywords: corporate governance, ownership separation, politics and public choice, securities markets, social democracy 


\title{
Corporate Governance AND Its Political ECONOMY
}

\author{
Mark J. Roe and Massimiliano Vatiero
}

Table of Contents

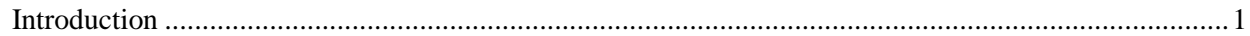

I. The Historical Organization of Capital Ownership in the United States............................................. 6

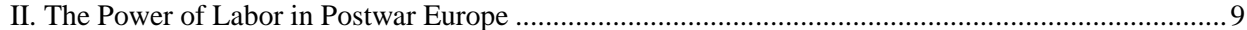

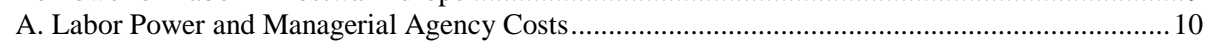

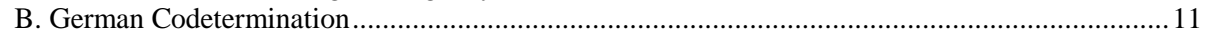

C. Data on Correlation of Labor Power and Close Ownership: Bidirectional Causation......................... 12

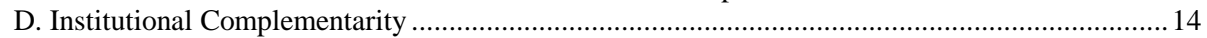

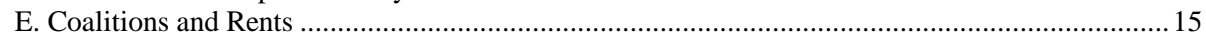

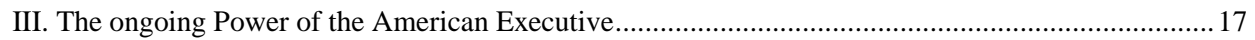

IV. Further Political Channels .................................................................................................. 20

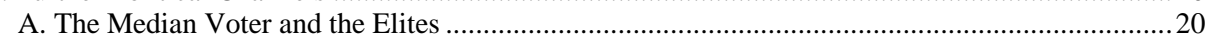

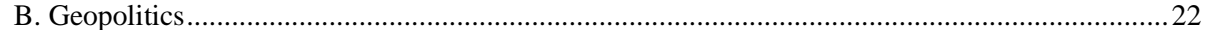

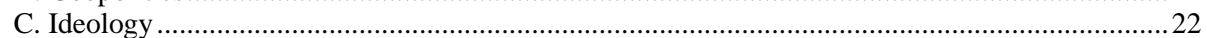

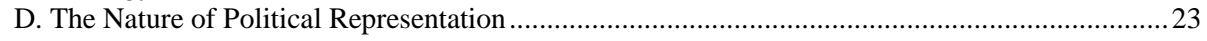

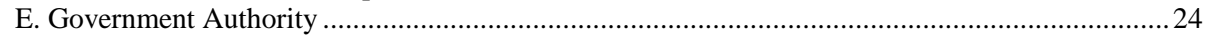

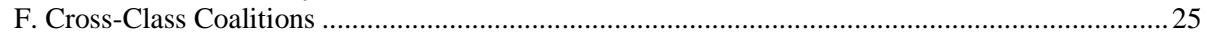

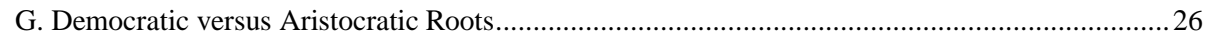

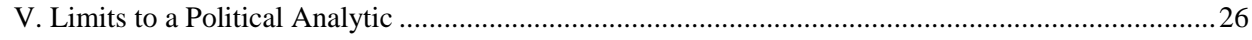

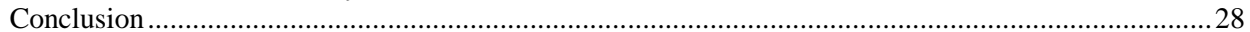

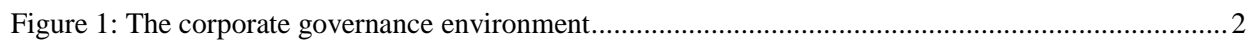

Figure 2: The "triangle" of political theory and corporate governance ..................................................... 3

Figure 3: Correlation between labor protection and corporate ownership diffusion .............................. 13

Figure 4: Correlation between product market regulation and corporate ownership diffusion.................16 


\title{
Corporate Governance and Its Political Economy
}

\author{
Mark J. Roe and Massimiliano Vatiero*
}

\section{INTRODUCTION}

To fully understand the modern corporation's ownership, shape, and distribution of authority, one must attend to politics. Because basic dimensions of corporate organization can affect the interests of voters, because powerful concentrated interest groups seek particular outcomes that deeply affect large corporations, because those deploying corporate and financial resources from within the corporation to buttress their own interests can affect policy outcomes, and because the structure of some democratic governments fits better with some corporate ownership structures than with others, politics can and does determine core structures of the large corporation.

Douglass North captures something close to the idea we seek to apply in this handbook essay: "institutions [for us here, the institutions of corporate governance] are not necessarily or even usually created to be socially efficient, rather they . . . are created to serve the interests of those with the bargaining power to devise [the] new rule." ${ }^{1}$ Interest groups often seek to obtain via politics both immediate results and enduring institutions that promote their own current interests and preferences. They do so generally and they do so in ways that can determine corporate governance. The results may be efficient, neutral or, sometimes, socially inefficient. ${ }^{2}$

Figures 1 and 2 illustrate the first generality of our argument here: the firm is embedded in financial, labor, and product markets, each of which affects the shape of the large firm and each of which attracts considerable attention of politics. The polity shapes the firm directly and, through these three markets, indirectly, as Figure 1 illustrates.

Moreover, the principal players inside the firm - corporate owners, executives, and employees - can themselves project power into the polity. Owners seek mechanisms that minimize agency costs, managers seek autonomy and prestige, and workers seek job stability and good wages; each seeks rules that favor themselves in contested transactions. They are at the three vertices in the triangle in Figure 2, with each side of the triangle representing a potential coalition between two of these actors. ${ }^{3}$ These three actors interact inside the firm ${ }^{4}$ and in the economy, and contend or

\footnotetext{
* Professor, Harvard Law School, and Assistant Professor ("Brenno Galli” Chair), Università della Svizzera italiana, respectively. Massimiliano Vatiero is grateful for hospitality to Harvard Law School and for support from Swiss National Science Foundation.

${ }^{1}$ Douglass C. North, Institutions, Institutional Change AND ECONOMiC PERFormance $16(1990)$.

${ }^{2}$ And, to be explicit, interest groups successes need not be socially efficient. Cf. Daron Acemoglu, Why Not a Political Coase Theorem? Social Conflict, Commitment, and Politics, 31 J. CoMP. ECON. 620 (2003).

${ }^{3}$ Cf. Francesco Parisi, Political Coase Theorem, 115 Public Choice 1, 11 (2003).

${ }^{4}$ One of first works on interactions among corporate owners, managers, and workers is MASAHIKO AOKI, THE CO-OPERATIVE GAME THEORY OF THE FIRM 33, 61-91, 119-28 (1984) ("it seems reasonable to
} 
coalesce in the political arena. Corporate governance arrangements inside the firm among these three main corporate actors interact deeply with a nation's politics through party systems, political institutions, political orientations of governments and coalitions, ideologies, and interest groups. ${ }^{5}$

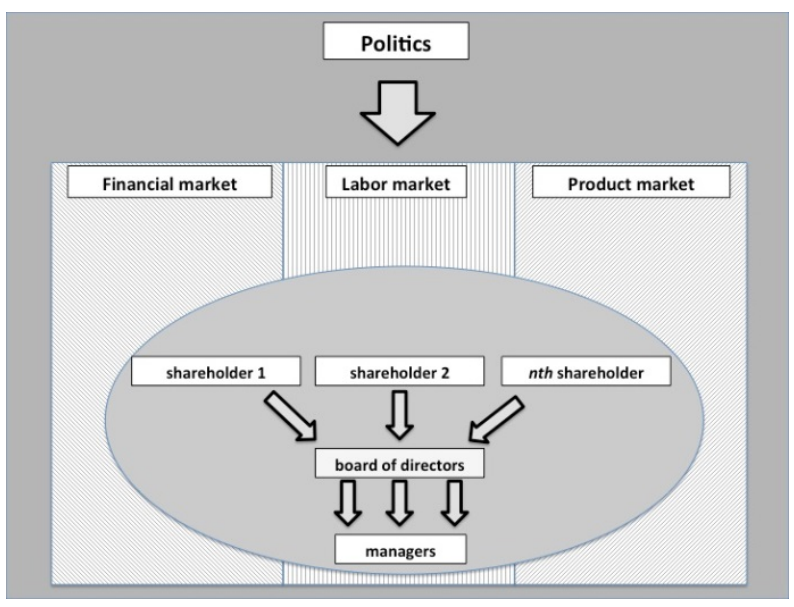

Figure 1: The corporate governance environment

A major part of the differences among corporate governance regimes in advanced industrial countries is determined by policies concerning labor protection, orientation to shareholder value, and product market conditions. How a polity decides to organize capital, labor, and product markets can deeply affect the firm's corporate governance structure.

Complications abound. A simple map from politics to economics to corporate governance cannot be written because causation is bidirectional, as the dotted arrows in figure 2 illustrate. Sometimes causation is circular, with several economic, institutional, and political features determined simultaneously. Sometimes there are multiple equilibria due to path-dependence phenomena, making the original conditions - which may result from chance, contestable events - determinative. Thus, the present corporate governance structure is the consequence of past politics and is also a cause of future politics and economic institutions.

characterize the firm as a field of bargaining among firm-specific resource-holders including the body of employees .... There does not seem to exist, therefore, a single objective of the firm such as the maximization of residual (profits); rather, the firm internalizes a bargaining process in which the conflicting objectives of the firm-specific resource-holders are brought into [an organizational] equilibrium within a framework of the co-operative relations”). Aoki did not investigate the influence of politics on these interactions inside the firm.

${ }^{5}$ See Mark J. Roe, Political Determinants of Corporate Governance. Political Context, Corporate Impact 4 (2003); Peter A. Gourevitch \& JAMES J. Shinn, Political Power and Corporate Control: The New Global Politics of Corporate Governance 59-67, esp. tbl. 4.1 at $60(2005)$. 


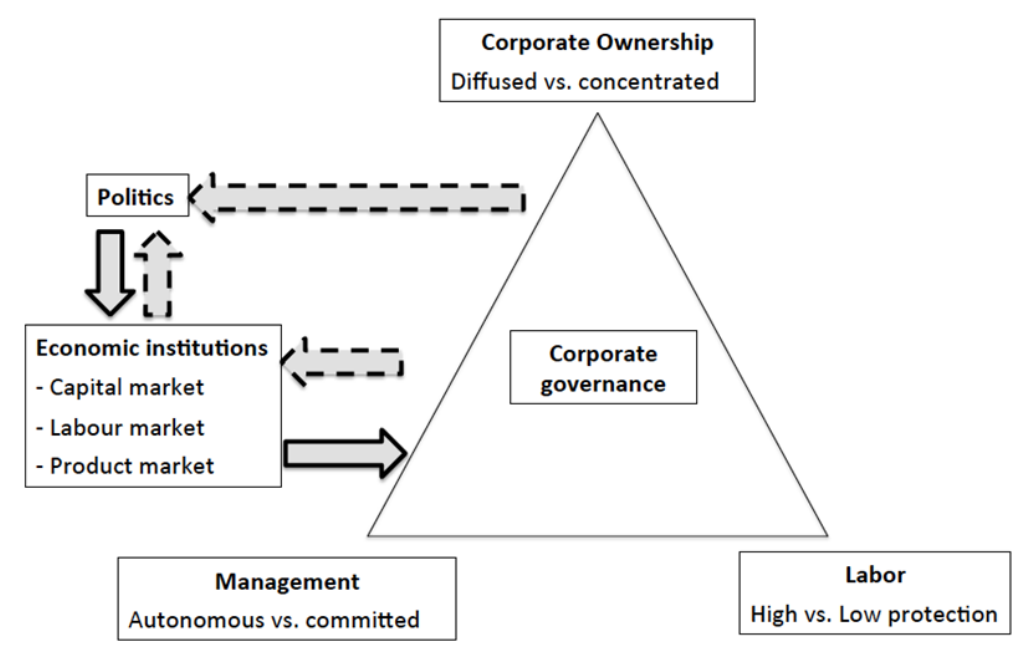

Figure 2: The “triangle” of political theory and corporate governance

Corporate structures around the world ${ }^{6}$ and over time $^{7}$ have been heterogeneous, with the differences seen as most important being "the structure of rights and responsibilities among the parties with a stake in the firm." "We focus on the large, usually public, firm, partly because the largest firms are the "most politically salient firms in every jurisdiction" 9 and the institutional differences in corporate governance are more evident in the largest business firms than in medium or small firms. "The different connotations of capitalism that spice political debates in different countries so differently are mainly due to differences in who controls countries' large corporations." 10

\footnotetext{
${ }^{6}$ The literature distinguishes between (at least) two modern models of corporate governance; some call the two a neoliberal model and a Rhenish-Alpine-Japanese model, MiCHAEL ALBERT, CAPITALISM AGAINST CAPITALISM (1993); others call them, an insider model and outsider model, JULIAN FRANKS \& COLIN MAYER, OWNERSHIP AND CONTROL, IN TRENDS IN BUSINESS ORgANIZATION: Do PARTICIPATION AND COOPERATION INCREASE COMPETITIVENESS? 174 (Horst Siebert, ed., 1995); others a market-system and hierarchical-control system, FrankLin Allen \& DOUglas Gale, Comparing Financial Systems (2000); and others call them an Anglo-American corporate governance and Continental European corporate governance, Ruth V. Aguilera \& Gregory Jackson, The Cross-National Diversity of Corporate Governance: Dimensions and Determinants, 28 ACAD. MGMT. REV. 447 (2003).

${ }^{7}$ See Julian Franks, Colin Mayer \& Stefano Rossi, Ownership: Evolution and Regulation, 22 REV. FIN. STUD. 4009, 4034 (2009) (evolution of corporate ownership in the United Kingdom over the twentieth century, with "the rate[] of dispersion in the first half of the century [being] generally higher than in the second half”; Julian Franks, Colin Mayer, \& Hideaki Miyajima, Equity Markets and Institutions: The Case of Japan (Am. Finance Ass'n 2010 Atlanta Meeting Paper), available at http://ssrn.com/abstract=1362613 (surprisingly high level of ownership dispersion in Japan in the first half of the twentieth century).

${ }^{8}$ MASAHIKO AOKI, INFORMATION, CORPORATE GOVERNANCE, AND INSTITUTIONAL DiVERSITY: COMPETITIVENESS IN JAPAN, THE USA, AND THE TRANSNATIONAL ECONOMIES 11 (2000).

${ }^{9}$ Paul Davies, Luca Enriques, Gerard Hertig, Klaus J. Hopt, \& Reiner Kraakman, Beyond the Anatomy, in Reiner KraAKMAN et AL., The ANATOMy of Corporate LAW: A Comparative AND FUNCTIONAL APPROACH 306 (2009).

${ }^{10}$ Randall K. Morck \& Lloyd Steier, The Global History of Corporate Governance, in A HISTORY

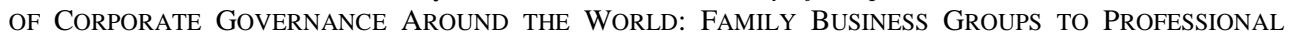
MANAGERS 8 (Randall K. Morck, ed., 2005).
} 
In this handbook essay, we examine three instances of vital intersections between politics and the organization of the modern corporation. In the first, we look at how the politics of organizing financial institutions affects the flow of capital into the large firm and, hence, the power and authority of shareholder-owners. The channels through which capital flows into the large firm can determine ownership structure and, hence, the distribution of governance authority in the large firm. If financial institutions are barred from owning stock or from operating on a large, national scale, to take an extreme example, then they will be unable to serve as a counterweight to managerial and board authority. Concentrated ownership with institutional blockholding will be difficult or impossible. Its opposite, diffuse ownership with strong managerial control, can readily become the only alternative if the polity prevents financial institutions from growing large or having a role in stock ownership and corporate governance. Powerful financial institutions will produce more of the former — blockholding — than of the latter — diffuse ownership with strong managerial control. ${ }^{11}$

Because the flow and organization of capital attracts political attention, corporate structure can be, and often has been, a consequence of politics. The United States historically kept financial institutions small and without authority to own stock and influence large firms, coming close to the extreme instance just mentioned. As a consequence, when American industry went national at the end of the nineteenth century, the continent-spanning industrial firms could not raise capital from a nationspanning financial market. Capital had to come from disparate institutions and individuals. In other nations tight relationships between large-scale industry and largescale finance were possible. As a result in the United States, the large public firm with diffuse ownership and powerful managers became more important, more widespread, and more persistent earlier than in other nations that had more concentrated financial institutions. Some of these patterns persisted well into and to the end of the twentieth century.

In the second instance, we examine the slowness of Continental European nations to develop diffusely-owned public firms in the decades after World War II. While the decades-long persistence of concentrated ownership was surely in important part due to economic forces, ${ }^{12}$ micro- and macro-politics strongly shaped the structure of the European firm. In particular, during the reconstruction after the Second World War, powerful labor movements in Western Europe made strong claims on firms' cash flows. Diffuse ownership in a strongly social democratic political environment was dangerous for dispersed shareholders. When labor made these strong claims on firm value, shareholders needed more and stronger mechanisms to keep executives loyal to shareholders. But because the polity would not provide such mechanisms readily, or at all, owners had reason to stay close to the firm to handle managerial agents themselves — either by directly running the firm's day-to-day operations or by keeping a close

${ }^{11}$ Marco Becht \& Colin Mayer, Introduction, in The Control of Corporate Europe. 1 (Fabrizio Barca \& Marco Becht, eds., 2001), call this the over-regulation thesis.

${ }^{12}$ Cf. Peter A. Hall \& David Soskice, An Introduction to Varieties of Capitalism, in VARIETIES OF CApitalism: The Institutional Foundations of Comparative AdVANTAGE 1-68 (Peter A. Hall \& David Soskice, eds., 2001), who contrast liberal and coordinated market economies, with concentrated ownership playing a more important role in the latter — common in postwar Europe — than in the former. 
eye on the managers who did. Shareholders could contain labor's claims on large firms' cash flows better if stock was in the hands of a close owner than with diffuse owners, which would lead to independent managers and an independent board running a diffusely-held firm. Hence, to keep the firm's operating managers more loyal to shareholders, close ownership persisted. ${ }^{13}$

The third example concerns management in diffusely-owned firms. Managers wield considerable political influence, which they use to shape the rules governing corporate finance and capital markets. In the 1980s, for example, American capital markets created the hostile takeover, by which an investor or another firm bought enough dispersed stock to control the targeted firm. Managers and directors sought to disrupt those hostile takeovers: transactionally, with poison pills, staggered boards, and antitakeover legislation and court rulings that made takeovers harder to accomplish.

The first two instances of the politics of corporate governance have the firm (or players inside the firm) reacting to the political environment. If the polity keeps capital channels fragmented, such as they were in the United States for the nineteenth and much of the twentieth centuries, then the firm learns how to deal with diffuse ownership. In the second instance, when labor makes particularly powerful claims on the firm's value, executives and owners of the firm learn how to create countervailing power inside the firm. In contrast, in the final example that we investigate here, we see players inside the firm - executives and boards — proactively seeking public policies that favor themselves. Those in command of the firm can project power into the polity and will use that power to maintain, and sometimes to obtain, corporate law that favors them and maintains their authority inside the firm.

In Part I, we examine how the fragmented financial system in the United Stated historically limited the institutional blockholders and heightened managerial autonomy. In Part II, we examine the relationships between owners and labor in polities where labor is strong, a corporate governance result well-exemplified by German codetermination. In Part III, we examine political explanations for the continuing power of the American executive and the American board during recent decades. In Part IV, we briefly look at other political economy channels for corporate governance. And in Part V, we look at the limits of a political economy analysis, before we conclude.

We do not assert that these three political channels exhaust all important political channels of corporate governance and, for completeness, we describe at the end of this essay several other channels, including some that need further research. Nor do we assert that analysis of economics, law, finance, contracts, institutional capacity, and lawmakers' sensibility of what's right and appropriate should be abandoned i.e., we do not assert that behind each such perspective is a political economy story. Our aim is rather to develop the perspective that corporate governance often reflects political choice and this channel can complement other efforts to explain the shape of the modern public corporation in the United States and around the world. More sharply, we claim that without political economy analytics, the shape, structure, and

${ }^{13}$ Cf. Harold Demsetz \& Kenneth Lehn, The Structure of Corporate Ownership: Causes and Consequences, 93 J. POL. ECON. 1155, 1158-60 (1985) (corporate ownership concentration provides scale economies in collecting information and monitoring managers). 
extent of the corporation, its ownership, and its place in an economy, cannot be understood.

\section{The Historical Organization of Capital OWNERShip IN THE UNITED STATES}

When the large firm became technologically possible at the end of the nineteenth century, the types of capital-providers were few: banks, insurers, governments, and individuals. There were no institutional investors like modern-day hedge funds, mutual funds, or pension funds. Individuals were major capital providers to, and owners of, the large firm, but the largest firms in the United States outstripped the financial capacity of even the richest individuals. John D. Rockefeller, the richest person in the United States at the time, owned only a fraction of Standard Oil's stock.

The question to consider here is why deposit-gathering banks (and large life insurers), which were the major financial players of the time, were not then major players in American corporate governance. The answer seems on the surface simple banks were barred from stock ownership throughout the era (and the insurers were barred eventually as well). Equally or more importantly, American banks were too small to play a role in major firm ownership anyway. ${ }^{14}$

A political economy explanation underlies the organization of American capital markets at the end of the nineteenth century. ${ }^{15}$ The United States had its unusual, fragmented financial system largely because the small banks were politically dominant in the United States and made sure that Congress would not disrupt their local monopolies. That history begins most plausibly with Andrew Jackson's 1830s destruction of the Second Bank of the United States, a large, nation-spanning bank that could have been the model for a continent-spanning financial system. Alexander Hamilton's had sought in the 1790s to create a truly national banking system. Several Congresses chartered, at Hamilton's urging at first, and then re-chartered a Bank of the United States, with branches in the major American cities of the time. But the smaller banks found themselves stressed and pressed by the Second Bank's quasi-regulatory efforts. ${ }^{16}$ In a Congress that was organized locally, district-by-district, the small, local bankers could be quite influential and they wanted Congress to rein in the Bank of the United States. Voter sentiment favored the small banks, making it easier for them to prevail. Jackson's famous at-the-time veto message tapped into populist sentiment that wanted finance small, local, and weak. ${ }^{17}$

Those forces - local banker power, American congressional structure, and American anti-big-bank populism — combined to keep the financial system weak (as compared to what was possible and to what emerged in other nations) for well over a

\footnotetext{
${ }^{14}$ See generally Eugene Nelson White, The Political Economy of Banking Regulation, 1864-1933, 42 J. ECON. HIST. 33, 34 (1982).

${ }^{15}$ See generally Mark J. Roe, Strong Managers, Weak OWners: The Political Roots of AMERICAN CORPORATE FINANCE (1994) ["Strong Managers, Weak Owners”]; Mark J. Roe, A Political Theory of American Corporate Finance, 91 COLUM. L. REV. 10 (1991).

${ }^{16}$ Roe, Strong Managers, Weak Owners, supra note 15, at 54-59.

${ }^{17}$ Bray Hammond, Jackson, Biddle, and the Bank of the United States, 76 J. ECON. HIST. 1 (1947); BRAY HAMMOND, BANKS AND POLITICS IN AMERICA FROM THE REVOLUTION TO THE CIVIL WAR 149-55 (1957); ARTHUR SCHLESINGER, JR., THE AGE OF JACKSON (1945).
} 
century. ${ }^{18}$ The United States during the nineteenth and much of the twentieth centuries had the most unusual banking system in the industrialized world: banking rules barred banks from operating on a national scale — and sometimes even a state-wide scale. ${ }^{19}$ Thus, by the end of the nineteenth century, although American industry was continentspanning, banks were small and local. Hence, industry could not gather capital from one, or a few, large deposit-gathering banks that provided one-stop financing. There was a major mismatch between the scale of American industry and the scale of American banking.

Insurers sought to fill the financing gap left by fragmented, local banking. And life insurers, whose obligations were long-term, were even better suited structurally for long-term big stockholdings than banks. The life insurers moved to fill the gap that American banking regulation created by taking large stock positions, initially in railroads and utilities. But the then-famous Armstrong investigation (which nearly propelled Charles Evans Hughes, its protagonist, to the presidency) culminated by barring life insurers from stock ownership. ${ }^{20}$ The consequence was that the weak and local structure of American banking combined with barring large life insurers from owning equity raised the demand and need for securities markets.

Although regulators intermittently sought to permit nation-wide banking, the small local bankers and their allies in Congress blocked their efforts. The National Bank Act, for example, passed to help finance the Civil War, created entities called "national" banks, but they were national only in the sense that Washington provided the charter and legal basis for them to operate. Their operations were largely local, as they were barred from operating from more than a single location. And, at the end of the nineteenth century, when industry was becoming national, the Treasury Department sought to allow banks to operate more widely geographically. Congress, presumably under the influence of the local bankers (and perhaps with public opinion still moved by an anti-big-bank animus) blocked these changes. ${ }^{21}$

Banks and insurers were the core financial institutions when industry went national and continued to be core for much of the twentieth century. With banks and

${ }^{18}$ By populism we mean "a widespread attitude that large institutions and accumulations of centralized power are inherently undesirable and should be reduced, even if concentration is productive [because] . . concentrated private groups can capture government.” Roe, Strong Managers, Weak Owners, supra note 15, at 29.

European intellectuals developed a similar view of concentrated economic power before and just after the turn of the twentieth century, with the idea closely associated with the so-called "Vienna Circle" of intellectuals, with Carl Menger and Eugen Bohm-Bawerk as leaders, and in Germany via the so-called Freiburg School. However, the ideas did correspond to a generalized populist movement Cf. DAVID J. Gerber, LaW and Competition in Twentieth Century Europe: Protecting Prometheus 240 (1998). But the intellectual view did not translate into the public sphere. Mass movements sought to obtain state power for their own uses, not to limit state power for all.

${ }^{19}$ Daniel C. Giedeman, Branch Banking Restrictions and Finance Constraints in Early-TwentiethCentury America, 65 J. ECON. HIST. 129, 129 (2005) ("For most of the early twentieth century the American banking system was more severely restricted by regulations than the system of almost every other developed nation. A particularly important set of these banking regulations prevented the formation of widespread branching networks. Banking laws prohibited nationally chartered banks from opening branches, and most state-chartered banks faced similar limitations. The result of these restrictions was a nationwide banking system composed mostly of individual unit banks").

${ }^{20}$ Cf. Roe, Strong Managers, Weak Owners, supra note 15, at 60-93.

${ }^{21}$ This political economy of fragmented American banking is set forth in id. at 51-145. 
insurers restricted in size and from stock ownership, financial institutions could thus not play a strong role in corporate governance. But with money to be made in industry by achieving large scale economies or sufficient market power to raise prices, firms found ways to raise money from bondholders and stockholders in diffuse securities markets. That result then created groups - small-town bankers with local monopolies - that wanted to preserve that status quo. As a consequence, as founders of nationspanning industrial firms left their positions, and no blockholder or influential financial institution replaced the founders, diffuse ownership shifted power to executives and boards, and these managerial players then also became interests that wished to preserve their authority relative to others inside the firm. With the firm lacking concentrated owners, these managers became, as we shall see, freer to act in the policy-making environment than close owners would have allowed them to be.

True, banks' and insurers' capacity to improve firm value is limited. Such financial institutions are not entrepreneurs or CEOs. For some industrial firms, financial blockholders may do little of value and the costs to the financial firm of holding big concentrated blocks may induce even legally authorized, large financial institutions to choose their blocks carefully. Yet, with the rise in recent years of blockholding hedge funds, we know that some investors will find blocks to be worth acquiring. ${ }^{22}$ The only question is one of extent. Overall the normative idea is that corporate governance value is probably lost if an organizational form is barred. The normative question then is (1) the size of the value lost and (2) whether better rules could have channelled institutions to the most value-enhancing results and away from value-diminishing channels.

If the corporate governance consequences here had limited impact on firm value, then the normative story becomes less important but the explanatory story more important. A limited operational value of the corporate governance choices suggests that even small political restraints can sharply shift power inside the firm. That is, if concentrated ownership and diffuse ownership are value-neutral choices for all firms, then political choices are easier for the polity to make, because the economic cost of the choice would then be low, or zero. The political choices may be serendipitous or depend on ephemeral political alignments. But if little value is lost from a modest political push, then the explanatory power of politics even more strongly explains the shape of authority inside the firm. ${ }^{23}$

${ }^{22}$ See generally Marcel Kahan \& Edward B. Rock, Hedge Funds in Corporate Governance and Corporate Control, 155 U. PA. L. REV. 1021 (discussing impact of hedge fund blockholding); Stuart Gillan \& Laura T. Starks, The Evolution of Shareholder Activism in the United States, J. APPLIED CORP. FIN. 55 (2007); and Alon Brav, Wei Jiang, Frank Partnoy, \& Randall S. Thomas, Hedge Fund Activism, Corporate Governance, and Firm Performance, 63 J. FIN. 1729 (2008) (for an empirical analysis of the influence of hedge funds on the corporate governance).

${ }^{23}$ Bradford J. DeLong, Did J.P. Morgan's Men Add Value?, in INSIDE THE BUSINESS ENTERPRISE (Peter Temin, ed., 1991) provides some of the better-known evidence that the costs of barring financial institutions from substantial governance roles were not small: In end-of-the-nineteenth-century America, the Morgan firm put its partners on firms' boards, thereby offering the firm's own reputation to protect shareholders from scurrilous or incompetent management. Pernicious insider dealings, or undiscovered managerial incompetence, would cost the Morgan firm dearly, so it warranted (albeit weakly) that such nefarious or incompetent results would be unlikely to occur in the firms on whose boards its partners sat. Outside investors might mistrust the firm and its inside managers, but they had more reason to trust the Morgan directors. 
The bottom-line here in terms of the structural outcome, apart from any normative economic story, is that these interest group and popular configurations left the United States with severe limits to national financial operations: the United States long lacked a national banking system, American banks lacked the power to engage in commerce and, generally, to own any stock at all, and insurance companies lacked the authority to own common stock for most of the twentieth century.

Although other nations have had some of these limits on banks and insurers, few have had them all. Banks and insurers in other countries historically played a role in corporate governance that was more vigorous than the role they played in the United States. Britain, for example, has had powerful insurers that owned or controlled significant stock positions, and continues to have such influential institutional stockholders. ${ }^{24}$ Germany has had universal banks with substantial stock ownership and even more powerful control of their brokerage customers' votes. ${ }^{25}$ Japan has had nation-spanning banks with significant stock ownership. ${ }^{26}$ The latter two channels of universal banks and main banks have narrowed in importance in the past several decades, although they have not disappeared.

\section{THe PoWer OF LABOR IN PostWAR EUROPE}

If labor makes powerful claims on large firms' cash flows, such that how the firms handle these pressures deeply affects shareholder value, then that labor power will affect corporate governance players' choices as to structure, ownership, and power allocations. Moreover, if labor is powerful across the polity, then its power can even more directly determine corporate governance. German codetermination, by which labor gets about half of the seats on public firms' boards, is an explicit instance. And more generally, labor power in Germany and elsewhere in social democratic countries affects ownership structure, by making diffuse ownership considerably less valuable for stockholders than close ownership. There is good reason to expect that in the immediate postwar decades in Western Europe this impact of labor's power was a large determinant of corporate governance. ${ }^{27}$

${ }^{24}$ Insurance companies are currently important investors in British equities, having owned approximately 20 per cent of the market since the early 1980s. Bernard S. Black \& John C. Coffee, Hail Britannia?: Institutional Investor Behavior Under Limited Regulation, 92 MICH. L. REV. 1997, at 2008-10 (1994). As Cheffins notes, unlike in the United States, there was no legislation in the United Kingdom during the twentieth century explicitly discouraging concentrations of shareholdings. Brian Cheffins, Putting Britain on the Roe Map: The Emergence of the Berle-Means Corporation in the United Kingdom, in CORPORATE GOVERNANCE REgIMES: CONVERGENCE AND DIVERSITY 147-72 (Joseph A. McCahery et al., eds., 2002). And in the modern era, other institutional investors have played a major role in large British firms.

${ }^{25}$ A universal bank not only takes demand deposits and make loans, but can also underwrite, hold, and trade all other securities. ALEXANDER GERSCHENKRON, ECONOMIC BACKWARDNESS IN HISTORICAL PERSPECTIVE: A BOOK OF ESSAYS (1962) argued that universal banking was critical to Germany's industrialization and that it is critically useful when countries catch up in industrial development. His thesis relates to the radical vs. incremental innovation discussion infra, in Part II.

${ }^{26}$ See Masahiko Aoki, Hugh Patrick \& Paul Sheard, The Japanese Main Bank System: An Introductory Overview, in JAPANESE MAIN BANK SYSTEM - ITS RELEVANCE FOR DEVELOPING AND TRANSFORMING ECONOMIES 3 (Masahiko Aoki \& Hugh Patrick, eds., 1995).

${ }^{27}$ See Mark J. Roe, Legal Origins, Politics and Modern Stock Markets, 120 HARV. L. REV. 462 (2006) [“Legal Origins”]. 
The general principle here is this: if labor makes strong claims on large firms' cash flows, then shareholders have reason to limit those claims. But executives who are not subject to strong shareholder control can readily "defect" from shareholder value, as the executives' preferred agenda for the firm often overlaps with labor's. Thus, labor and management of a diffusely-held firm may have similar agendas in polities with strong labor pressures, and that combined agenda may more sharply differ from that of owners in strong labor environments than in weak labor environments. That difference makes the diffusely-owned firm more costly for owners in strong labor environments.

For diffuse stock markets to arise and persist, the diffuse capital owners must see their firms as managed closely enough for stockholders, as compared to close ownership's value for stockholders. The public firm provides liquidity and diversification for the original investors and brings in professional managers to run the firm. But for the original dominant shareholders to turn their firm's ownership over to liquid stock markets and, hence, to managerial control, they must expect value from turning over control. If the benefits to stockholders of shareholder liquidity and professional management are exceeded by the costs of turnover due to increased managerial disloyalty because the polity will not support the institutions and rules that facilitate managerial loyalty to shareholders, then fewer dominant stockholders will turn their firms over to managers than otherwise.

\section{A. Labor Power and Managerial Agency Costs}

Consider the range of agency costs that explained widespread hostile takeovers in the United States in the 1980s: a managerial tendency to expand the firm beyond its efficient boundaries, a managerial tendency to spend the firm's free cash-flow instead of returning it to shareholders, a managerial preference for low-risk operations that do not threaten the firm and managers' positions, and a managerial tendency to use up capital in place even when the firm no longer was profitable rather than move the capital elsewhere. Michael Jensen's 1986 analytic is the iconic one of the time. ${ }^{28}$ These managerial agency costs (if one considers the managers to be working primarily for shareholders) map closely onto the goals of powerful labor: to expand the firm to keep employment up, to spend free cash-flow on wages and salaries, to avoid risky operations that threaten jobs and factories, and to avoid closing down factories even if they are no longer profitable. In such a pro-labor environment, shareholders would have a high demand for the tools that would keep managers pro-shareholder. Their demand for such tools presumably would exceed shareholders' demand for such tools in the United States in the 1980s, as the United States lacked such strong labor pressures. That is, even without such labor pressures, managerial agency costs in diffusely-owned firms have been sufficiently important that shareholders sought tools to reduce those costs. Labor pressures as in Germany would have made those costs even higher.

${ }^{28}$ Michael Jensen, Agency Costs of Free Cash Flow, Corporate Finance and Takeover, 76 AM. ECON. REV. 323 (1986). Cf. Michael Jensen \& William Meckling, Theory of the Firm: Managerial Behavior, Agency Costs and Ownership Structure, 3 J. Fin. ECON. 305 (1976). 
For shareholders to count on executives being satisfactorily loyal to shareholder goals, shareholders need institutions and norms that reward that loyalty and that give them means to detect and punish disloyalty. But if a polity will not provide those institutions, or if it denigrates such shareholder-value norms, then dominant stockholders can obtain more shareholder value for themselves by keeping control of the firm. Managerial control will not ordinarily appear in such a political environment and will be unstable if it does. Stock markets will not be strong in such nations, because managerial agency costs will be too high and too hard to lower to levels that stockholders would find acceptable. ${ }^{29}$

More texture: A polity in which labor was often the decisive political player would not facilitate managerial shareholder-loyalty mechanisms, such as takeovers, incentive compensation, and corporate transparency for shareholders, as these tools would not be in labor's interest. Without shareholders having those tools, the costs to shareholders of labor power could be large. Consider a firm that contemplates a major expansion into a new market or contemplates whether to take advantage of a new technology to re-orient its production. If the expansion fails or the technology backfires in a weak labor environment, the firm contracts and reverses the expansion. The contraction and reversal are costly, but achievable, limiting losses to shareholders. Such expansions and, if needed, contractions are common in the United States. But if a prolabor environment makes contraction and reversal even more costly because it would trigger government inquiry and costs, or if contraction is functionally impossible because the polity and its labor rules will not allow layoffs or make them very costly, then the downside costs to shareholders of misdirected expansion rise. ${ }^{30}$ Yet, a basic agency managerial cost is posited to be that managers seek larger firms for prestige, power, and often compensation. In a prolabor environment, shareholders would be especially wary of the firm expanding and would therefore want the upside to be particularly strong and the probability of the downside low. Shareholders with weak corporate governance tools could readily find that the best way to prevent unwarranted expansion is for them to keep a close eye on managers. For them to keep a close eye on managers, they would have to keep close ownership of the firm. And that is approximately what we saw in Western Europe in the immediate postwar decades.

\section{B. German Codetermination}

German codetermination, as noted above, provides the most direct labororiented corporate governance mechanism here, with German law requiring that half of the seats on the German supervisory board be reserved for employees. It resulted from political compromises: Codetermination of labor and shareholders arose just after the Second World War in the coal and steel industry. Labor delegates in the boardroom would, it was thought, constrain the wartime industrialists. In one rendition of the postwar explanation, labor's presence in the boardroom would weaken the wartime industrialists' influence and, hence, the victorious Allies did not need to dismantle the

\footnotetext{
${ }^{29}$ See Roe, Political Determinants, supra note 5, at 29-37.

${ }^{30}$ Id.
} 
steel and coal industry to pacify Germany. ${ }^{31}$ Later political events, such as labor unrest, led to settlements to have the rest of industry codetermined. ${ }^{32}$

Codetermination is best seen as an amalgam of political objectives, like the goal of industrial and political leaders for labor peace, and the realpolitik that labor had considerable voting power in the polity. Either way - whether by compromise or power play - codetermination directly determines core aspects of German corporate governance, namely the composition of the board of directors, and it is a political economy result. The German supervisory board has a major labor presence and, because the supervisory board appoints the management board (which runs the firm day-to-day), there is a major difference in power and governance in the German firm as compared to, say, the American firm. German senior managers typically need some level of labor support, or acquiescence. ${ }^{33}$

The logic of the incentives that codetermination creates should foster concentrated ownership as well, in the manner suggested above for prolabor polities. With employees wielding power in the supervisory board, shareholders would typically do better for themselves overall if they maintained strong countervailing power in the boardroom, as well as means to monitor managers directly outside of the boardroom. The obvious way to do both would be to maintain concentrated ownership.

\section{Data on Correlation of Labor Power and Close Ownership: Bidirectional Causation}

Figure 3 illustrates the relationship between labor power (quantified by union and job security rules ${ }^{34}$ ) and the degree to which large firms had large blockholders in the year 1995. Greater labor power coincides with greater ownership concentration, weaker labor power with more diffuse ownership. ${ }^{35}$ Wealthy nations with high employment protection and high labor power lack diffuse stock markets; conversely, nations with high stock market diffusion and fewer large controlled firms do not vigorously protect employees with jobs in place. Essen, Oosterhout and Heugens bring

${ }^{31}$ In Italy, the Allies also preferred to preserve incumbent large firms. Cf. Fabrizio Barca, Katsuhito Iwai, Ugo Pagano \& Sandro Trento, The Divergence of the Italian and Japanese Corporate Governance Models: The Role of Institutional Shocks, 23 ECON. SYSTEM 25 (1999).

${ }^{32}$ See Katharina Pistor, Codetermination: A Sociopolitical Model with Governance Externalities, in EMPloyeEs AND CoRPORATE GovernAnCE 163 (Margaret Blair \& Mark J. Roe, eds. 1999). For a recent analysis of the changes in German corporate law that facilitated ownership dispersion (but without a political interpretation), see Wolf-Georg Ringe, Changing Law and Ownership Patterns in Germany: Corporate Governance and the Erosion of Deutschland AG, _ AM. J. COMP. L. _ (2015, forthcoming).

${ }^{33}$ Cf. Pistor, supra note 32, at 191; and Roe, Political Determinants, supra note 5, at 29-33.

${ }^{34}$ Roe, Legal Origins, supra note 27, at 497 (tbl. 7).

${ }^{35}$ See Mark J. Roe, Political Determinants, supra note 5, at 52; Marco Pagano \& Paolo F. Volpin, The Political Economy of Corporate Governance, 95 AM. ECON. REV. 1005 (2005); Beth Ahlering \& Simon Deakin, Labor Regulation, Corporate Governance, and Legal Origin: A Case of Institutional Complementarity?, 41 L. \& SoCIETY REV. 865 (2007); Marianna Belloc \& Ugo Pagano, Co-evolution of Politics and Corporate Governance, 29 INT'L REV. L. \& ECON. 106 (2009): Marianna Belloc \& Ugo Pagano, Politics-Business Co-evolution Paths: Workers' Organization and Capital Concentration, 33 INT’L REV. L. \& ECON. 23 (2013). 
forward good evidence that relational blockholders are better than other owner types at handling powerful labor pressures. ${ }^{36}$

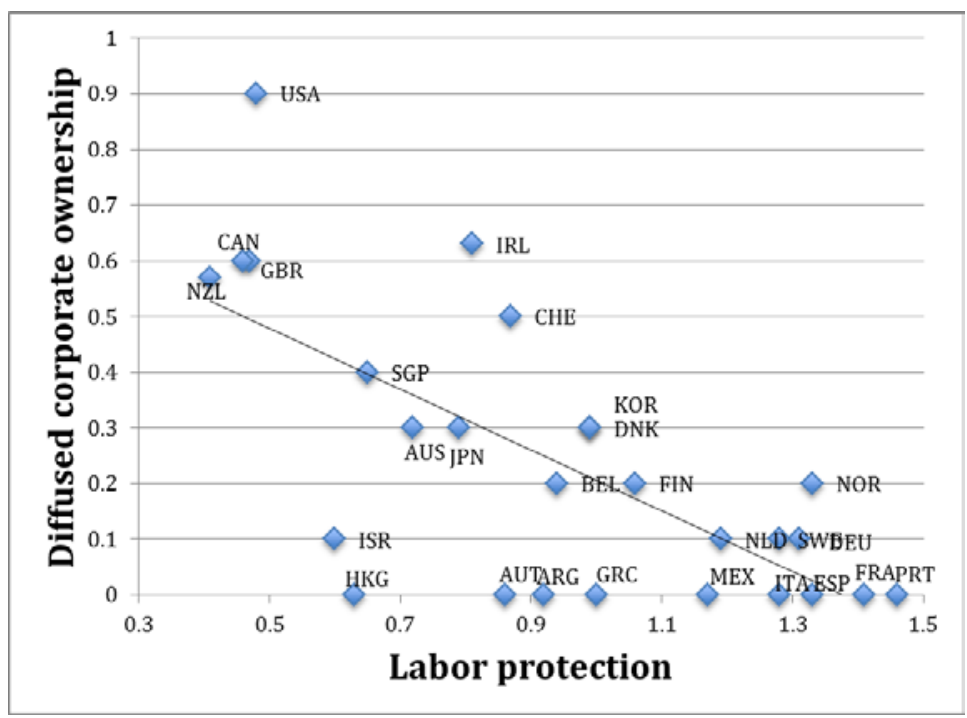

Figure 3. Correlation between labor protection and corporate ownership diffusion.

The 27 countries represented are Argentina (ARG), Australia (AUS), Austria (AUT), Belgium (BEL), Canada (CAN), Denmark (DNK), Finland (FIN), France (FRA), Germany (DEU), Greece (GRC), Hong-Kong (HKG), Ireland (IRL), Israel (IRS), Italy (ITA), Japan (JPN), Mexico (MEX), the Netherlands (NLD), New Zealand (NZL), Norway (NOR), Portugal (PRT), South Korea (KOR), Singapore (SGP), Spain (ESP), Sweden (SWE), Switzerland (CHE), the United Kingdom (GBR), and the United States (USA). $y=-0.55 x+0.75$; R-squared= 0.47 ; $\mathrm{p}$-value $<.02 ; \mathrm{n}=27$. We include here all nations for which the ownership data is available. One sees that the sample includes a handful of less developed nations, whose inclusion would not change the relationship. Sources and background to the figure can be found in Roe, Legal Origins, supra note 27, at 497, tbl. 7).

The negative correlation between labor power and shareholder power is striking, making this a good spot to raise the possibility, indeed the likelihood, of bidirectional causation. Thus far, the thesis of this part has been that blockholding persistence is a reaction to labor power. It's of course possible, indeed even likely, that some of labor's power comes from the polity reacting negatively to blockholding, as one additional way, through the polity, for employees to shift value and authority in the firm away from owners and toward themselves. (In their view, the shift would perhaps be back to themselves, as a matter of economic justice.)

Concentrated ownership may induce workers to seek employment protection privately via unions and contracting, as well as publicly via employment and antilayoff rules; that is, ownership concentration may induce employees to call for protection via politics:

[E]arly in the twentieth century, the visible power of Germany's large banks, people's envy and resentment of rich industrialists, and the disorientation and anomie induced by Germany’s rapid transformation from an agricultural nation into

${ }^{36}$ Marc van Essen, J. Hans van Oosterhout \& Pursey Heugens, Competition and Cooperation in Corporate Governance: The Effects of Labor Institutions on Blockholder Effectiveness in 23 European Countries, 24 ORG. SCI. 530 (2014). 
an industrial one helped to call forth codetermination to tame the bankers and industrialists, and to give the workers a voice in the strange new industrial enterprises. ${ }^{37}$

\section{Institutional Complementarity}

This reverse causation between corporate ownership and labor protection corresponds to a literature on institutional complementarity. ${ }^{38}$ Briefly, in some economies labor training and skills better complement ownership structures that facilitate labor stability than other ownership systems. Choices in one domain, such as labor protection, act as exogenous parameters in other domains (e.g. the corporate ownership), and vice-versa.

Similarly, innovation systems are complementary to ownership systems, ${ }^{39}$ and determining one economic piece of the corporate governance structure via politics can lock in other elements of the large firm. Corporate governance with large shareholders and highly protected workers supports incremental innovation that requires more cooperation among stakeholders than sharp, radical innovation, as noted above, whereas diffuse ownership and weak employee protection facilitate radical innovation, by allowing new production technologies and new products to quickly disrupt labor arrangements. ${ }^{40}$ Whatever innovation system is in place then interacts with political demands for corporate governance, as noted in Part IV. Incremental innovation systems calls forth labor protection and, consequently or directly, blockholder ownership. Radical innovation calls for the corporate governance systems with limited commitments to labor and ongoing trading partners.

Overall, as long as institutional complementarities are deep and strong, they can affect, or conceivably determine, the institutional equilibrium, and that system will differ depending on which local complement dominates.

${ }^{37}$ Roe, Political Determinants, supra note 5, at 112-13.

38 See Hall \& Soskice, supra note 11. Cf. MASAHIKO AOKI, TOWARDS A COMPARATIVE Institutional ANALYSIS (2001); Bruno Amable, Institutional Complementarity and Diversity of Social Systems of Innovation and Production, 7 REV. INT'L. POL. ECON. 645 (2002); Martin Gelter, The Dark Side of Shareholder Influence: Managerial Autonomy and Stakeholder Orientation in Comparative Corporate Governance, 50 HARV. INT'L L.J. 129 (2009); Ugo Pagano, The Evolution of the American Corporation and Global Organizational Biodiversity, 35 SEATTLE U.L. REV. 1271 (2012); Ugo Pagano \& Massimiliano Vatiero, Costly Institutions as Substitutes: Novelty and Limits of the Coasian Approach, _ J. INST. ECON. _ (2015) (forthcoming).

${ }^{39}$ Wendy Carlin \& Colin Mayer, Finance, Investment, and Growth, 69 J. FIN. ECON. 191, 193 (2003) ("financial and ownership systems are associated with different types of corporate activities and investments”) (emphasis in original). See generally Hall \& Soskice, supra note 12. Griffith and Macartney provide empirical evidence on these theoretical issues. Rachel Griffith \& Gareth Macartney, Employment Protection Legislation, Multinational Firms, and Innovation, 96 REV. ECON. \& STAT. 135 (2014).

${ }^{40}$ Gilson and Roe advance a different explanation for the Japanese case. They see Japanese managers' ability to close down parts of the inter-firm labor market as more important for developing firmspecific human capital than firms' commitment to keep the employees working. Ronald J. Gilson \& Mark J. Roe, Lifetime Employment: Labor Peace and the Evolution of Japanese Corporate Governance, 99 CoLUM. L. REV. 508 (1999). 


\section{E. Coalitions and Rents}

Thus far in this Part, we have considered the possibility that owners seek to keep managers loyal in high-labor-power environments. This roughly corresponds to the line linking employees and owners in the Figure 2 triangle above. Next we consider another such linkage between owners and employees.

Consider first Rajan and Zingales's showing that blockholders will often want to suppress financial market development, particularly if product market competition is weak, because easier access to financing for upstarts would more likely erode blockholders' monopoly rents. ${ }^{41}$ Hence, poor shareholder protection should correlate with trade protectionism. ${ }^{42}$

Although this is not prima facie a labor-oriented explanation, it could become so. Indeed, since in a functioning democracy the blockholders do not necessarily get their way with the polity if voters do not agree, ${ }^{43}$ labor can play a role in buttressing the incumbent blockholders. ${ }^{44}$ If labor obtains a portion of the rents that accrue to the firm (and its blockholder) with insufficient competition, then this sector of labor also disfavors financial development. They ally with the blockholders, either directly or more likely via coalition voting in parliament to defeat financial liberalization. In this way Rajan and Zingales's blockholder interest explanation can be deepened and extended with labor power in the postwar European democracies. In this amendment to the blockholder power theory, labor at established firms allies with incumbent blockholders to exert influence in the polity to protect their mutual interests. ${ }^{45}$

Blockholders and incumbent workers may ally to create or maintain monopoly rents, which can be split between them; the two can influence the polity to keep trade barriers high and financial competition weak:

${ }^{41}$ Blockholder power can be magnified if it's a function of what the blockholder controls rather than the monetary value of what it owns. Consistently, Morck, Wolfenzon and Yeung show that family control via pyramids amplifies the owners political influence relative to their actual stakes. Randall Morck, Daniel Wolfenzon \& Bernard Yeung, Corporate Governance, Economic Entrenchment, and Growth, $43 \mathrm{~J}$. ECON. LIT. 655 (2005).

42 Raghuram Rajan \& Luigi Zingales, The Great Reversals: The Politics of Financial Development in the Twentieth Century, 69 J. FIN. ECON. 5 (2003). A related generalized version is advanced by Enrico Perotti \& Paolo F. Volpin, Lobbying on Entry (Working paper, London Business School 2004), available at http://ssrn.com/abstract=558588 . For the regular influence of families in dominant businesses on politics, often in developing nations, see Randall Morck \& Bernard Yeung, Family Control and the Rent-Seeking Society, 28 EnTREPRENEURSHIP: THEORY AND PraCtice, 391 (2003).

${ }^{43}$ Anonymous, disparate, especially individual (as opposed to institutional) shareholders seem to be a classic instance of Mancur Olson's “inchoate group”, namely a group that, although large, is too scattered an poorly organized to influence political decisions than smaller, but organized groups such as corporate executives. MAncur Olson, The Logic of Collective Action: Public GOODS AND THE THEORY OF GROUPS (1965).

${ }^{44}$ See Roe, Political Determinants, supra note 5, at 134-149.

45 That is, labor is not a unified block, but divided between labor at core industries (which allies directly or through their parliamentary representatives) with blockholders, on the one hand, and labor in outside or less-influential industries, on the other hand. See DAVID RUEDA, SOCIAL DEMOCRACY INSIDE OUT: PARTISANSHIP AND LABOR MARKET POLICY IN ADVANCED INDUSTRIALIZED DEMOCRACIES 2, 6, 12-22 (2008) (analyzing Spain, Britain, and the Netherlands in such terms); Assar Lindbeck \& Dennis J. Snower, The Insider-Outsider Theory: A Survey (IZA Discussion Paper No. 534 2002), available at http://ssrn.com/abstract=325323. 
[W]ith the monopolies in place in a democracy, the benefited owners have to get other players' political support. Union and employee benefits, instead of being 'grabs', could be 'pay-offs' from owners, to keep political and internal support strong for hampering competitors. Or, slightly differently, employees and owners can coalesce politically, aiming to weaken competitors, both domestic and foreign, via blocking rules, subsidies, and trade barriers. ${ }^{46}$

Figure 4 provides evidence of the negative correlation between product market competition and the diffusion of corporate ownership.

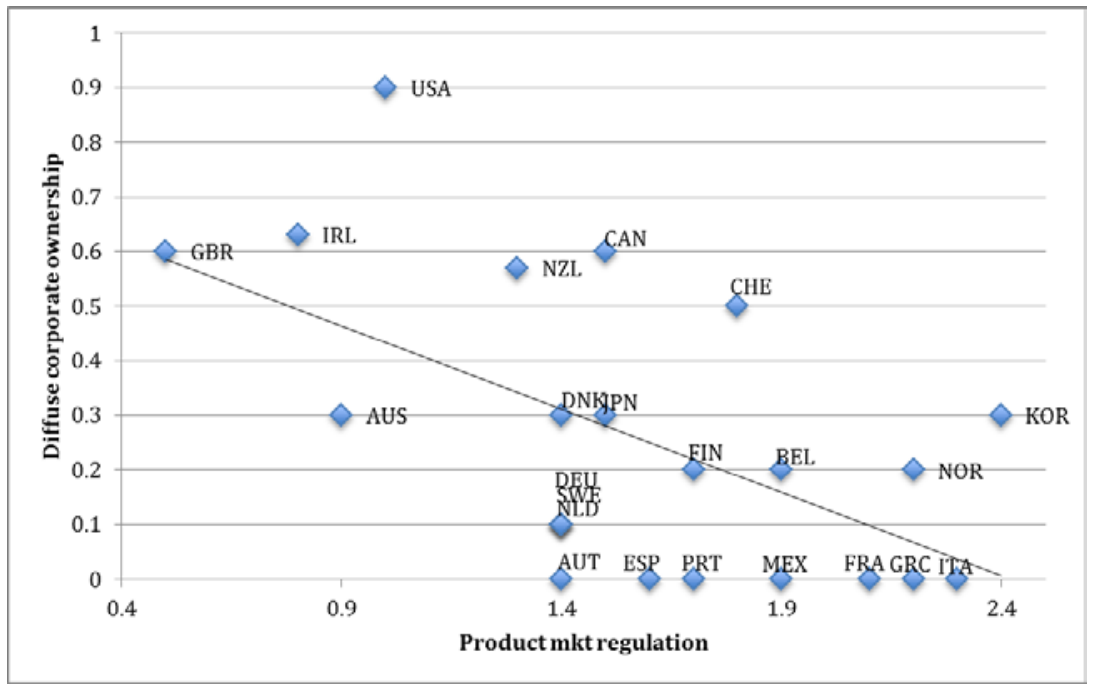

Figure 4. Correlation between product market regulation and corporate ownership diffusion

The 23 countries are Australia (AUS), Austria (AUT), Belgium (BEL), Canada (CAN), Denmark (DNK), Finland (FIN), France (FRA), Germany (DEU), Greece (GRC), Ireland (IRL), Israel (IRS), Italy (ITA), Japan (JPN), Mexico (MEX), the Netherlands (NLD), New Zealand (NZL), Norway (NOR), Portugal (PRT), South Korea (KOR), Spain (ESP), Sweden (SWE), Switzerland (CHE), the United Kingdom (GBR), and the United States (USA). $y=-0,3047 x+0,7374$; R-squared $=0.33$; $p$-value $<.02$; $n=23$. Sources: corporate ownership is see figure 3; product market regulation see Giuseppe Nicoletti, Stefano Scarpetta \& Oliver Boylaud, Summary Indicators of Product Market Regulation with an Extension to Employment Protection Legislation, OECD Econ. Dep't working paper no. 226, at 79, tbl A3.6 (2000), who measure how deeply product markets are regulated, which presumably causes or is correlated with weaker product market competition. Diffuse ownership is from Rafael La Porta, Florencio Lopez-de-Silanes \& Andrei Shleifer, Corporate Ownership Around the World, 54 J. Fin. 471, 494 tbl. 3 (1999), which tabulates the portion of the ten firms with a December 1995 stock market capitalization of common equity of just above $\$ 500$ million that lack a $20 \%$ blockholder.

Weaker product markets and the concomitant monopoly rents can affect corporate governance by loosening constraints on managers and/or by setting up a fertile field where shareholders can cooperatively split rents with incumbent workers. ${ }^{47}$ Large ownera and incumbent workers can ally politically in order to frustrate competition policy and its related financial market policy.

${ }^{46}$ Roe, Political Determinants, supra note 5, at 139.

${ }^{47}$ See Roe, Political Determinants, supra note 5, at 125-49; Peter A. Gourevitch, The Politics of Corporate Governance Regulation, 112 YALE L.J. 1829, 1841 et seq., 1871 et seq. (2003). 
Related but differing political economy explanations for corporate governance have emerged, which we discuss further in Part IV.

In this Part, we have argued that the structure of markets that the large firm faces, the power of labor in the polity overall, and the power of labor vis-à-vis the large firm all deeply affect the large firm. Some ownership structures can do better than others in the face of muscular labor. And when labor is powerful, it can determine corporate structures directly, as is the case for German codetermination. The degree of labor power also affects structures pervasively. Managerial agency costs need to be contained, or so shareholder interests demand, and those managerial agency costs in public firms are harder to contain in prolabor environments. Hence, shareholders have less reason to favor diffuse ownership when labor is powerful. The postwar European evidence suggests that they in fact disfavored diffuse ownership and preferred concentrated ownership.

\section{The Ongoing Power of the American Executive}

Managers of large diffusely owned firms have reason to disrupt their shareholders' capacity to aggregate their stock ownership in ways that would project more shareholder power into the firm's boardroom. The executives may not own much of the firm's capital themselves, but they control the firm and they seek to maintain their control; powerful stockholders would limit executive autonomy. Managers thus seek laws that impede or bar hostile takeovers and that make large, active shareholder positions costly for shareholders. They oppose voting rules that would make it easier for shareholders to elect directors other than those whom incumbent managers support. Such rules are more likely to arise and persist in countries like the United States, where diffuse ownership prevents blockholders from vetoing managerial influence in lawmaking, because there are fewer blockholders. In countries in which concentrated blockholders tightly control the firm, managers could not readily seek such rules, because the powerful stockholder would be unhappy with such managerial lobbying.

These managerial efforts to affect the terms of basic corporate and securities law have been significant in the United States historically and continue today. Managers successfully opposed the strongest proposals in this past decade to allow shareholders easy access to the firm's proxy statement, which would allow dissidents to more easily elect directors. ${ }^{48}$ Prior outbreaks of the shareholder voting reform efforts in the United States, starting in the 1940s, also died after managers successfully opposed the proposals. The literature on the spillover of managerial preferences and authority into the political sphere is thinner. ${ }^{49}$

The 1980s economic circumstances presented a powerful twin challenge to senior American executives' autonomy. Large manufacturers were challenged by the rise of international competition, mostly from Germany and Japan. And

\footnotetext{
${ }^{48}$ Mark J. Roe, The Corporate Shareholder's Vote and Its Political Economy, in Delaware and in Washington, 2 HARV. BUS. L. REV. 1 (2012).

${ }^{49}$ Efforts can be found Mark J. Roe, Takeover Politics, in THE DEAL DECADE 321-52 (Margaret Blair, ed. 1993); Joseph A. Grundfest, Subordination of American Capital, 27 J. FIN. ECON. 89 (1990); and Lucian A. Bebchuk \& Zvika Neeman, Investor Protection and Interest Group Politics, 23 REV. FIN. STUD. 1089 (2010).
} 
simultaneously the hostile takeover rose to prominence: a takeover entrepreneur would acquire the funding to buy a target firm's stock and then appeal over the heads of executives and the board to the firm's shareholders. If the shareholders sold their stock to the takeover entrepreneur - often a person, investor group, or another large firm - the takeover entrepreneur would own the company and, often enough, replace the firm's managers.

Managers reacted swiftly and ferociously, building up antitakeover transactional tactics and, when those failed - several were barred by courts in early decisions the managers sought changes in the law to facilitate their ability to fend off hostile takeovers. The typical antitakeover transactional tool became the poison pill, which would dilute the value of the takeover entrepreneur's stake. The tactic needed validation from courts and legislatures that it was a permitted managerial tool. Eventually, the managers got that authorization and (along with other antitakeover tools) beat back the hostile takeover wave. ${ }^{50}$ As a consequence of the political battles over takeovers, power shifted further to the board of directors in large American firms by the 1990 s. ${ }^{51}$

Some of the managers' success in beating back hostile takeovers was due to the strength of their lobbying organizations (such as Chambers of Commerce and the Business Roundtable) in influencing state legislatures to validate antitakeover tools and leave court decisions in place that permitted poison pills. Two political economy aspects ought to be noted. First, the managers' lobbying organizations did well on their own, but acquired even more heft by the fact that employees and voter opinion were mostly on their side. This roughly corresponds to an alliance between employees and managers, one side of the Figure 2 triangle. Both managers and employees typically seek stability. Moreover, public opinion was against the hostile takeover, even if it wasn't for the manager. ${ }^{52}$

One can see a managerial-labor coalition as decisive in making for some state anti-takeover law. ${ }^{53}$ When a Pennsylvania corporation was targeted for a hostile takeover, it sought strong anti-takeover law from the state's legislature. For many Pennsylvania legislators, voting for the legislation was easy, as both the Chamber of Commerce and the AFL-CIO supported the legislation. Consider a contemporary comment:

\footnotetext{
${ }^{50}$ Cf. Emiliano Catan \& Marcel Kahan, The Law and Economics of Anti-Takeover Statutes (NYU Law and Econ. Working Papers, 2014), available at http://ssrn.com/abstract=2517594.

${ }^{51}$ Stephen M. Bainbridge, The New Corporate Governance ANd Practice (2008).

52 Roberta Romano, The Future of Hostile Takeovers: Legislation and Public Opinion, 57 U. CincinnAti L. REV. 457 (1988). Cf. Roe, Strong Managers, Weak Owners, supra note 15, at 152-53.

${ }^{53}$ John C. Coffee Jr., Shareholders versus Managers: The Strain in the Corporate Web, 85 MiCH. L. REV. 1, 70 (1986) ("Employees and managers constitute the best example of a class that has had to accept the imposition of higher risk. Many recent instances can be identified where corporations first leveraged up as a takeover defence and then followed this action with subsequent massive dismissals or compelled retirements of employees”); Geoffrey Miller, Political Structure and Corporate Governance: Some Points of Contrast between the United States and England, 2 Colum. Bus. L. Rev. 51 (1998). Cf. Martin F. Hellwig, On the Economics and Politics of Corporate Finance and Corporate Control, in Corporate Governance: Theoretical and Empirical Perspectives 95, 134 (Xavier Vives, ed., 2000) (showing how the convergence of interests between managers and workers at the corporate level may induce them to converge on a common platform at the political level); Marco Pagano \& Paolo F. Volpin, Managers, Workers, and Corporate Control, 60. J. FiN. 841 (2005); Marco Pagano \& Paolo F. Volpin, Shareholder Protection, Stock Market Development, and Politics, 4 J. EUR. ECON. Ass’N 315 (2006).
} 
[The] lobbying effort is the product of teamwork between ... Pennsylvania labor unions and a coalition of over two dozen corporations working for the passage of the bill under the well-organized direction of the Pennsylvania Chamber of Business and Industry ${ }^{54}$

Many states also contemporaneously enacted constituency statutes, which formally authorized boards to weight the impact of hostile takeovers on corporate constituencies, like employees, when deciding whether to reject or accept an outside bid. In time, boards successfully defeated hostile takeovers when the poison pill was fully validated. When they did, constituency statutes played a limited role thereafter in takeovers.

True, economic circumstances eventually undercut the hostile takeover in that the 1980s hostile takeover was most efficacious for breaking up the 1960s' conglomerates. Once most were broken up and their separate businesses spun off, there were fewer sweet spots for easy money takeovers. And in time, the takeover machinery monetized incumbent managers' positional advantage, with hostile takeovers ceasing but "friendly" takeovers proceeding. Nominally these takeovers were "friendly" and the managers, who often departed, departed very rich. ${ }^{55}$

$$
* * *
$$

We can combine this Part's focus on managerial political power with the first Part's focus on the historical weakness of nation-spanning financial institutions in the United States. With managers in control of large firms early, due to the lack of a strong financial counterweight to managerial authority, they were freer to use political levers to maintain their authority. By beating back takeovers in the 1980s, by weakening proxy fights in the 1950s, and more generally by reducing or reversing reformers' success in creating rules that would strengthen shareholders and weaken managers, managers maintained their position of authority. Were blockholders in place, managers could not as readily have lobbied for rules that extend or maintain managerial autonomy and authority.

That is, path dependence affects the corporation and some of that path dependence operates through political channels. ${ }^{56}$ Once there is diffuse ownership and managerial autonomy, for whatever reason, then those with power in the firm can project that power into the polity to resist new laws that would reduce their autonomy. That chain of events makes a first- and second-order, path-dependent political economy explanation plausible: autonomy first developed because American politics independently made banks and insurers, the institutional investors of their time, too weak to play a corporate governance role. Diffuse ownership ensured, without controlling shareholders who, one assumes would have looked askance at seeing their CEOs and senior executives seeking to cut back on shareholder power. Managers thus

${ }^{54}$ As quoted in Roe, Takeover Politics, supra note 49, at 393.

${ }^{55}$ Marcel Kahan \& Edward B. Rock, How I Learned to Stop Worrying and Love the Pill: Adaptive Responses to Takeover Law, 69 U. CHI. L. REV. 871 (2002) (incumbent managers bought off).

${ }^{56}$ See Mark J. Roe, Chaos and Evolution in Law and Economics, 109 HARV. L. REV. 641 (1999); Lucian R. Bebchuk \& Mark J. Roe, A Theory of Path Dependence in Corporate Ownership and Governance, 52 STAN. L. REV. 127 (1999). 
had substantial power to operate in the political arena independent of shareholders, and they used that freedom to act in the political arena to bolster their autonomy. As in other path-dependent settings, an early decision and structure affects a later decision, tending to preserve the earlier structure.

Moreover, one can see the ongoing importance of political economy explanations for corporate governance through another political channel. Substantial managerial power may simply originate from the baseline efficiency of separating ownership from control. That separation then gives managers authority in the firm, which they can project into the political sphere, further enhancing their authority beyond that which would have prevailed in an efficient, politically neutral setting.

The converse is also true. Once controlling shareholders are dominant across most firms in a given polity, they will tend to use their resulting political power to maintain their controlling positions. For example, in some polities, controlling shareholders can shift value to themselves more easily than in other jurisdictions. Reformers might want to change these rules, lowering the private benefits of control to controllers-by devising rules and processes by which small shareholders can reverse related-party transactions between the firm and the controlling insiders, and restricting the ease with which controlling shareholders can squeeze out minority stockholders at an unfair price. But once a player controls a public firm, it has an interest in maintaining (or expanding) its capacity to shift value to itself. ${ }^{57}$ When many controlling shareholders are in place in an economy, they become influential in the polity. This feature seems to have been important in recent decades in several Western European nations. $^{58}$

\section{Further Political Channels}

In this Part, we examine a (partial) list of further interactions between politics and corporate governance in developed countries.

\section{A. The Median Voter and the Elites}

Politicians seek out the median, pivotal voter, who determines elections in a democracy. ${ }^{59}$ In particular, Perotti and von Thadden show how the preferences of the pivotal voter can depend on the size and form of the returns to human capital relative to the voter's return from financial assets. ${ }^{60}$ If the median voter has substantial financial assets, then she will support financial development and securities markets. But if the median voter has relatively low financial savings and relatively high human capital, then the median voter will prefer low-risk, go-slow economic policies overall and will have little personal interest in supporting securities markets. That preference arises because a financially weakened middle class is largely concerned about the labor

\footnotetext{
${ }^{57}$ Bebchuk \& Roe, supra note 56, at 149-50, 158-60.

${ }^{58}$ See infra Part IV; RANDAll MorCK, ED., CONCENTRATEd CORPORATE OWNERShip (2000).

${ }^{59}$ ANTHONY DOWNS, AN ECONOMIC THEORY OF DEMOCRACY (1957).

${ }^{60}$ Enrico C. Perotti \& Ernst-Ludwig von Thadden, The Political Economy of Corporate Control and Labor Rents, 114 J. Pol. ECON. 145 (2006). Cf. Hans Degryse, Thomas Lambert \& Armin Schwienbacher, The Political Economy of Financial Systems: Evidence from Suffrage Reforms in the Last Two Centuries (SSRN working paper, 2013), available at www.ssrn.com/abstract=2378239.
} 
income risk associated with freer markets and supports a more corporatist financial system characterized by dominant banks. Banks are dominant because they profit from low-risk loans and their strong presence in corporate governance keeps firms less risky, which is what employees want. In Germany, firms with stronger labor have more bank debt, with the explanation being "that both employees and debt providers have a strong interest in the long-term survival and stability of the firm[,]" ${ }^{\prime 61}$ with other profit-maximizing goals presumably subordinate.

This median voter thesis relates to the idea that labor, if powerful, prefers block ownership to diffuse ownership. ${ }^{62}$ True, workers might well prefer weakened, dispersed shareholders to strong blockholders. Indeed, if the shareholder side becomes weaker, then the corporation is more likely to follow more of labor's preferences. But, workers, particularly if they own only small financial stakes, may prefer risk-reducing banks or large family shareholders to diffused shareholders if they believe that the former will typically choose safer, incremental operational strategies. In contrast, a strong equity market will presumably lead to more pro-equity, risky ventures that disrupts workers' lives and jobs. This abstraction largely describes Western Europe in the latter part of the twentieth century.

Culpepper analyses how corporate actors have been able to influence the development of corporate governance law in France, Germany, the Netherlands, and Japan. ${ }^{63}$ When an issue has low political salience to the median voter, then it will likely be decided through "quiet politics," in which corporate actors are preeminent. This is particularly so for those issues that strongly affect corporate actors' interests, such as laws on hostile takeovers. In contrast, where political salience is high, companies are not able to rely on quiet politics, and must instead seek partisan political protection more directly, and try to counter or change public opinion. "Business [elites] frequently lose[] political battles when the general public pays attention to them [regulatory politics], because when the public pays attention to issues, political parties start paying attention to the opinion of the median voter and stop paying attention to powerful interest groups." 64

In this perspective, median voter theory explains the corporate governance outcomes for issues that are salient for the average voter, but fails when the issue is not salient for voters. When it is not salient, the institutions of corporate governance will follow elite's preferences. Rajan and Zingales argued that controlling shareholders had little reason to support corporate governance reform that would undermine their

${ }^{61}$ Chen Lin, Thomas Schmid \& Yuhai Xuan, Employee Representation and Financial Leverage (working paper, Dec. 31, 2014), available at www.ssrn.com/abstract=2544223.

${ }^{62}$ However, the populist movement in the United States that fragmented the financial system included also the labor class.

63 Pepper D. Culpepper, Quiet Politics and Business Power: Corporate Control in EUROPE AND JAPAN 3-4, 177 (2011) ("the more the public cares about an issue, the less managerial organizations will be able to exercise disproportionate influence over the rules governing that issue. In other words, business power goes down as political salience goes up").

${ }^{64}$ Id. at 6. Rhodes and van Adeldoorn structure a similar argument: if corporate elites see their authority challenged, they will resist corporate governance reforms strongly, often strongly enough to overcome general voter sentiment. Martin Rhodes \& Bastiaan van Apeldoorn, Capital Unbound? The Transformation of European Corporate Governance, 5 J. EUR. PUBLIC POLICY 406 (1998). 
interests, particularly if the reform would foment better access to funding for upstart competitors of incumbent elites. ${ }^{65}$

\section{B. Geopolitics}

A related, geopolitical conceptualization may be also in play. The looming presence of the Soviet Union in the second half of the twentieth century was the central geopolitical fact for continental Europe. In the initial post-war elections, the communist party did well in France (about 20\% of votes from the 1950s to 1970s) and Italy (about 25\% of the vote from the 1950s to 1980s), making it important for centrist and conservative parties to co-opt the communist program, which they did. The result was policy that favored incumbent labor and incumbent owners. ${ }^{66}$

\section{Ideology}

We should not ignore the power of ideas and ideologies (or culture in a broad sense). For instance, Aguilera and Jackson report that cross-national differences in managerial behavior depend on differences in managers' world-views, with the differences in world-view highly influenced by education. Specifically, managers in the United States are typically well educated in finance and socialized in business schools to have a shareholder value orientation. In contrast, German managers more typically hold advanced degrees in technical fields such as engineering and thus tend to adopt a corporatist view of the firm as serving multiple interests and constituents. ${ }^{67}$ Finally, Allen documents that in Japan even junior high school textbooks stress that companies should be managed in the interests of all stakeholders. ${ }^{68}$

Ideology can affect corporate governance in ways that go beyond the ideas and training patterns for senior managers, because ideology, whether or not tied tightly to material interests, can affect the organization of finance and the rules that govern the large firm. As we saw above, anti-power populism in the United States favored the fragmentation of the banking system, while in Europe, social democratic ideologies ${ }^{69}$ supported empowering employees more and pressured managers to side with employees instead of owners, thereby creating conditions conducive to the concentration of corporate ownership in response.

While ideologies surely often correspond to material interests, we should not discount the possibility that some societies and some polities conceptualize how to handle problems and conflicts and that some of these conceptualizations have a life

\footnotetext{
${ }^{65}$ Rajan \& Zingales, supra note 42.

${ }^{66}$ For analysis of such a result in Italy, see Fabrizio Barca, Katsuhito Iwai, Ugo Pagano \& Sandro Trento, The Divergence of the Italian and Japanese Corporate Governance Models: The Role of Institutional Shocks, 23 ECON. SYSTEM 25 (1999).

${ }^{67}$ Aguilera \& Jackson, supra note 6, at 458-59.

${ }^{68}$ Franklin Allen, Corporate Governance in Emerging Economies, 21 OXFORD REV. ECON. POL'Y 164, 173 (2005).

${ }^{69}$ By social democracy we mean a nation committed to private property, but where distributional considerations are vital, where labor is typically powerful, and where government action to foster economic equality is central to the political agenda. See ADAM PRZEWORSKI, CAPITALISM AND SOCIAL DEMOCRACY 8 (1985); Shannon C. Stimson, Social Democracy, in The New PALgRAVE: A Dictionary of ECONOMICS 395-96 (John Eatwell et al., eds. 1987).
} 
independent of material interests. For example, the widespread belief in social democracy prevailing in Europe for several decades after World War II was partly due to the shared experience of the world war and the economic devastation it wrought. ${ }^{70}$

The strength of these European social democratic views has diminished in recent decades. Presumably, underlying interests have changed — basic manufacturing has shifted to a service-oriented economy, reducing the size of the blue collar vote. Savings have increased, altering the median voter's interests. ${ }^{71}$ Moreover, other influences can affect ideas without necessarily being based only or primarily in narrow self-centered interest. Until the 2008-2009 financial crisis, market-oriented economies performed well; European communism collapsed with the Berlin Wall in 1989, making socialist policies less likely to be seen as successful.

Whatever the underlying explanations, the broad shift in the polity toward a market orientation and a weakening of social democratic thinking has been recently measured and documented. ${ }^{72}$

That political shift in opinion and interests allows for more complex political configurations in recent years. Left parties that once opposed financial market development came to promote it. ${ }^{73}$ The left of the 1990s did not have the same policy views as the left of the 1960s or 1970s. That shift can be seen in the data of mutating party ideologies ${ }^{74}$ and can be grasped intuitively by comparing Tony Blair's marketfriendly Labour Party to Callaghan's hard-left Labour Party of the 1970s.

Unstated is the possibility that as the economy shifted from basic manufacturing to services, there were simply fewer labor voters for the left parties to appeal to. More generally, when the power of the left subsided, corporate owners and executives could more readily obtain their policy preferences. Culpepper so argues for recent decades. ${ }^{75}$ (We wonder whether that could have been true in the immediate postwar decades beyond the extent to which the executives' agenda overlapped with labor's.)

\section{The Nature of Political Representation}

Pagano and Volpin show that corporate governance regimes may be the result of the political mechanisms of preference aggregation rather than of political preferences. ${ }^{76}$ They suggest that a proportional system predicts weak shareholder

\footnotetext{
${ }^{70}$ Cf. Roe, Legal Origins, supra note 27, at 498-501.

${ }^{71}$ Enrico C. Perotti \& Armin Schwienbacher, The Political Origin of Pension Funding, 18 J. Fin. ECON. 384, 387, 402 (2009).

${ }^{72}$ Mark J. Roe \& Travis G. Coan, Financial Markets and Political Center Gravity (Working paper 2014).

73 Helen Callaghan, Insiders, Outsiders, and the Politics of Corporate Governance, How Ownership Structure Shapes Party Position in Britain, Germany, and France, 42 COMP. POL. STUD. 733 (2009); John W. Cioffi, Public LAW AND Private Power: Corporate GovernanCE Reform in the Age of Finance Capitalism (2010); John Cioffi \& Martin Höpner, The Political Paradox of Finance Capitalism: Interests, Preferences, and Center-Left Party Politics in Corporate Governance Reform, 34 Politics AND Society 463 (2006); Pablo M. Pinto, Stephen Weymouth \& Peter Gourevitch, The Politics of Stock Market Development, 17 REV. INT’L POL. ECON. 378 (2010).

${ }^{74}$ Roe \& Coan, supra note 72.

${ }^{75}$ Culpepper, supra note 63, at 3-4.

${ }^{76}$ Marco Pagano \& Paulo F. Volpin, The Political Economy of Corporate Governance, 94 AM. ECON. REV. 1005, 1007, 1009-11 (2005).
} 
protection and strong employment protection, while a majoritarian system predicts the opposite: strong shareholder protection and weak employment protection. The intuition behind these results is that proportional voting pushes political parties to cater more to the preferences of social groups with homogenous interests; that is, managers and employees, whose party representatives can ally and make deals in the parliament. ${ }^{77}$

Mueller shows further how first-past-the-post electoral systems, such as those in the United States, can affect corporate governance outcomes. ${ }^{78}$ In such political systems, a national interest group, such as labor, needs to persistently recapture a working majority in the legislature, working district by district, legislator by legislator. This process is costly for interest groups. But in a party-list system, the identity of the particular legislator is not vital to the interest group getting that legislator's vote: the legislator follows party discipline, thereby facilitating national deal-making in which national labor institutions can be quite influential. First-past-the-post territorial elections make national coalitions harder to create and maintain. It's thus no accident that Tip O'Neill's famous aphorism-that all politics is local-came from an American national politician, the locally elected leader of the House of Representatives, a legislative body that is a collection of locally elected representatives who make national policy.

Persson and Tabellini have developed an analogous argument. ${ }^{79}$ The state sector will be smaller in majoritarian than in proportional representation systems because competition for votes is in marginal districts rather than nationwide. Politicians accordingly will make smaller commitments in majoritarian systems, because they only need support from voters in the marginal districts. Broader interest groups will therefore get larger support in proportional than majoritarian systems.

\section{E. Government Authority}

A basic political economy feature is the allocation of authority between the government itself and private sector players who command capital. Government often seeks to obtain for itself capital that it lacks or seeks to command its use in the private sector, often in ways that favor a dominant governing coalition. In extreme form, a non-democratic, dictatorial government could prefer to directly allocate capital itself, stifling the development of a private sector in general, which might become a counterweight to the dictatorial government itself, and determining corporate results.

Governmental authority can be a mask for private interests. But we mean something more. Governmental authorities can build, shape, or destroy capital markets and economic institutions, for their own reasons and not just as tools of other interests or ideologies. One can recast the concept as a variant of Weingast's dilemma under

\footnotetext{
${ }^{77}$ Gourevitch \& Shinn, supra note 5, nicely develop this perspective further.

${ }^{78}$ Dennis C. Mueller, The Economics and Politics of Corporate Governance in the European Union, in INVESTOR PROTECTION IN EUROPE: CORPORATE LAW MAKING, THE MiFID AND BEYOND 3-30 (Guido Ferrarini \& Eddy Wymeersch, eds., 2006). Cf. Torben Iversen \& David Soskice, Electoral Institutions, Parties and the Politics of Coalitions: Why Some Democracies Redistribute More than Others, 100 AM. POL. SCI. REV. 165 (2006) (proportional representation facilitates center-left redistributive coalitions, as compared to majoritarian and presidential systems).

${ }^{79}$ Torsen Persson \& Guido Tabellini, The Size and Scope of Government: Comparative Politics with Rational Politicians, 43 EUR. ECON. REV. 699 (1999).
} 
which a government that is "strong enough to protect property rights . . . is also strong enough to confiscate the wealth of its citizens." ${ }^{80}$ Governmental authorities may denigrate a rival power center.

Moreover, governmental authorities could be susceptible to beliefs that capital markets will not produce social welfare and that government needs to direct and control capital flows to better produce wealth or justice. ${ }^{81}$ In this conceptualization, governmental authorities are themselves an interest, seeking power and enhanced authority.

Finally, governmental authorities may see government action as the vanguard of economic and social development; in pursuing policies to implement their goals, they can crowd out private capital markets and thereby prevent them from developing nicely. ${ }^{82}$ As an example, consider the following statement from William O. Douglas, the well-known 1930s chair of the Securities and Exchange Commission (SEC): people who dominate financial markets, he said, have "tremendous power. . . . Such [people] become virtual governments in the power at their disposal. [Sometimes it is] the dut[y] of government to police them, at times to break them up...."83 True, Douglas's view on governmental power may simply reflect that he favored the underlying interests that such a policy would favor. But one should not neglect the possibility that government authorities are themselves an interest group seeking to forward their own interests and ideology, with their own interests distinct from those in the civil, nongovernmental society. Their own direct interests and beliefs can motivate their actions vis-à-vis capital markets. This sub-category may be more vivid in authoritarian nations, but one should not assume its absence in the governments of the rich democracies.

\section{F. Cross-Class Coalitions}

We have seen conflicts and coalitions among different classes. Here, we describe sectoral and cross-class divisions, which have captured the attention of political scientists who consider corporate and related issues. Hall and Soskice, as well as Iversen and Soskice, emphasize that preferences and interests may follow the production technologies and, hence, can be dissimilar for owners in different sectors and for labor in different sectors. ${ }^{84}$ Blockholding and employment protection fit well with incremental innovation, they argue, and accordingly owners, managers, and employees in incremental sectors prefer political and corporate institutions that protect employees and facilitate blockholding, each of which facilitates incremental technical

${ }^{80}$ Barry R. Weingast, The Economic Role of Political Institutions: Market-Preserving Federalism and Economic Growth, 11 J.L. ECON. \& ORG. 1 (1995).

${ }^{81}$ To see an extreme instance of political leaders' belief systems affecting economic results, of which corporate governance and ownership would be a part, consider the case of South and North Korea. The current economic differences are largely due to "Rhee, Park, and other South Korean leaders believ[ing] in the superiority of capitalist institutions and private property, while Kim II Sung and Communist Party members in the North believed that communist policies would be better for the country." Acemoglu, supra note 2, at 632.

${ }^{82}$ Cf. Roe, Strong Managers, Weak Owners, supra note 15, at 36-42.

${ }^{83}$ William O. DOUglas, DemOCRACY AND FinANCE 11, 14 (1940).

${ }^{84}$ See Hall \& Soskice, supra note 12; Torben Iversen \& David Soskice, An Asset Theory of Social Policy Preferences, 95 AM. POL. SCI. REV. 875 (2001). Cf. Gourevitch, supra note47, at 1854-57. 
improvement. Owners, workers, and employees are all committed in such sectors to working with specific assets. ${ }^{85}$ The German economy represents an example of this system.

In contrast, corporate governance with dispersed owners and weak employee protection fits well with radical innovation, limited commitments, and flexible assets. Assets are more likely to be general-purpose. The American economy exemplifies this system.

\section{G. Democratic versus Aristocratic Roots}

Ugo Pagano argues that the diversity of corporate governance systems rests on political conditions existing when "big business" emerged in a country. ${ }^{86}$ If a robust democratic system had already developed when large firms emerged, then democratic politics would likely have challenged the concentration of economic power. With democratic politics limiting the power of large firms and their owners, there was less intensity in the demand from employees for counterbalancing, powerful unions. These democratic roots, hence, supported the public company with diffused corporate ownership, because neither side in the corporate power balance needed to concentrate excessively.

In contrast, if a robust democratic system had not emerged before large firms developed, then social-democratic power and unions were more likely to have arisen as a counterbalance to owners' political and economic power. These non-democratic roots explain a pattern different from one illustrated for democratic roots. ${ }^{87}$ In this perspective, the United States and Switzerland are two modern economies that had democratic systems at the time of industrialization and, hence, had diffused corporate ownership as a by-product. Most continental European countries, in contrast, are generally economies that were not democracies when they industrialized and, hence, they did not limit concentrated corporate ownership.

\section{Limits to a Political Analytic}

Without a political economy analytic, one can neither fully understand the structure of the modern corporation nor account for international differences. The way capital is organized and how those with authority in the firm project their power into the political sphere to maintain their internal authority are both basic determinants of the modern corporation.

But there are limits to the political economy analytic. First off, white it gives us insight into the broad patterns, it does not give us granularity and precision in understanding specifics. It is not a substitute for the practice of law, for comprehending

${ }^{85}$ Oliver E. Williamson, The ECONOMiC Institutions of CAPITALiSM 30-34, 52-56, 60-62, 95, 96, 301 (1985). Specific investments have little or no value outside a relationship but great value inside.

${ }^{86}$ Ugo Pagano, The Evolution of the American Corporation and Global Organizational Biodiversity, 35 SEATTLE L. REV. 1271, 1272-73 (2012).

${ }^{87}$ Cf. BARrington MoORE, JR., SOCIAL ORIGins OF Dictatorship AND DEMOCRACY 20-22 (1966). Moore points out that the landed aristocracy was stronger in some nations that industrialized and weaker in others. Its strength varied in Europe, but was typically much stronger there than the landed elite was in the United States. Cf. Pagano, supra note 81, at 1270-71). 
judicial opinions, and constructing the corporate statutes. It is big picture, not transactional.

Second, even the broad patterns are sometimes applicable only to subsets of nations. The social democratic analytic set forth above broadly explains the situation in the wealthy West in the decades after World War II, but is less good at explaining corporate structures and the (lack of) public markets in less developed and/or more authoritarian polities. But even here, a political economy analytic is needed to fully explain the financial and corporate phenomena. Financial markets and ownership separation cannot and do not develop well in politically unstable environments, with that political instability having economic inequality as a primary determinant (because the unequal have much to contest). Such politicized explanations have been brought forward and hold promise. ${ }^{88}$

Third, political economy explanations often lack predictability, ${ }^{89}$ because the political process is often dominated by local, ${ }^{90}$ geographic, and historical specifics. Some aspects that seem unpredictable, when properly analyzed, strongly fit with a political theory. For example, some have raised the idea that European social democratic parties, particularly in the 1990s, promoted investor protection, calling this shift a political paradox. ${ }^{91}$ However, the European polity had shifted sharply from the 1950s, moving from polities that were not attuned to markets to polities that grudgingly accepted market-oriented policies. Data is consistent. Again, a comparison illustrates: Tony Blair's Labour party was much more market-oriented than, say, the 1970s Labour Party of James Callaghan and Harold Wilson. To equate the 1990s Labour Party with that of the 1960s in order to conclude that politics is unpredictable is a comparison that risks conceptual error. Data is broadly consistent: polities moved pro-market as financial markets deepened. ${ }^{92}$

Fourth, the political economy analytic lacks strong normative content. It does not tell us what the best corporate policies are, other than perhaps to warn one off of policy initiatives that would lack political support.

${ }^{88}$ Mark J. Roe \& Jordan Siegel, Political Stability's Impact on Financial Development, 39 J. Comp. ECON. 279 (2011); Mark J. Roe \& Jordan Siegel, Finance and Politics: A Review Essay, 47 J. ECON. LiT. 782 (2009). Cf. Sibylle Lehmann-Haemeyer et al., The Political Stock Market in the German Kaiserreich - Do Markets Punish the Extension of the Benefit of the Working Class? Evidence from Saxony, 74 J. ECON. HIST. 1140, 1163 (2014) (“investors [in turn of twentieth century Saxony] feared a revolution. . . . [I]nvestors supported more participation of the middle and working class, possibly for reasons of political stability, but opposed it if they felt this influence became too large.”).

${ }^{89}$ Indeed, legislators must create institutions that stabilize coalitions and outcomes. Kenneth Shepsle, Institutional Arrangements and Equilibrium in Multidimensional Voting Models, 32 AM. J. POL. SCI. 27 (1979); Donald P. Green \& Ian Shapiro, Pathologies of Rational Choice Theory 99-120; Richard D. McKelvey, Intransitivities in Multidimensional Models and Some Implications for Agenda Control, 12 ECON. THEORY 472 (1976).

${ }^{90}$ For instance Mark Freeman, Robin Pearson \& James Taylor, Law, Politics and the Governance of English and Scottish Joint-Stock Companies, 1600-1850, 55 BUS. HIST. 633 (2013), examine joint-stock firms in England and Scotland before 1850 and present evidence that local political institutions played a bigger role in shaping organizational forms and business practice than the legal system. (The Scottish legal system differs from England's.)

${ }^{91}$ Cioffi \& Höpner, supra note 73, at 502. See also Pablo M. Pinto, Stephen Weymouth \& Peter Gourevitch, supra note 73.

${ }^{92}$ See Roe \& Coan, supra note 72. 
Lastly, and importantly from an academic perspective, some - perhaps too many - political explanations are susceptible to a narrative but not a test and regression. In econometric terms, political events are often low-frequency occurrences - one nation, one era, one political deal. That is, some political processes happen once, in one nation, and then become embedded in institutions, politics, and corporations. One cannot readily test how important the one-off decision was and what would have happened if contingent decisions came out differently.

The American history of banking is one such instance. The impact of social democracy on the corporation is more susceptible of testing since multiple nations went through the experience.

\section{CONCLUSION}

We have here pushed forward a main thesis with three subsidiary examples. The main thesis is that the shape of the public corporation will attract political attention in wealthy democracies, and democratic politics will accordingly affect the allocation of authority in the large public corporation in a major way. Politics can determine and indeed has determined the ways in which capital flows into the large firm, shattering financial channels into weak tributaries in the United States for the nineteenth and much of the twentieth century. The consequence of shattered financial channels is that the large public firm could not readily have major and powerful shareholders. Boards and executives had more autonomy than they otherwise would have had. The BerleMeans corporation with diffuse ownership and powerful managers was a political construct as much as it was an economic one.

When labor makes powerful claims on a large firm's cash flow, shareholders have reason to keep large offsetting blocks to reduce the strength of those claims. Postwar European polities had such a setting, and one major reason that blockholding by financial institutions like banks and insurers and by stockholding families persisted in the postwar decades seems to have been to offset labor's claims.

Once a corporate governance system is in place, corporate players can project power into the polity and can use that political power to maintain their corporate authority. Managers in the United States fit that example, as they have repeatedly blocked transactions and legal changes that would confine their authority and shift power from themselves to others, typically shareholders, in the large public firm. 